\title{
Managing the operation of trucks: methodological aspects of evaluating the efficiency and justifying reserves to increase cargo turnover
}

\author{
Vladimir Fedoskin ${ }^{1, *}$, Galina Bakulina ${ }^{1}$, and Maria Pikushina ${ }^{1}$ \\ ${ }^{1}$ Ryazan State Agrotechnological University Named after P.A. Kostychev, 390044 Ryazan, Russian \\ Federation
}

\begin{abstract}
The article outlines certain methodological aspects of substantiating ways to increase the efficiency of using freight transport. One of the priority areas in training highly qualified specialists in the economic field is teaching them the most rational and objective methods of analysis, the results of which are necessary for the development and substantiation of real and objective management decisions, the implementation of which in production and financial activities of enterprises will help to increase the economic efficiency of using material resources, including trucks. The system of performance indicators for the work of freight transport includes summarizing and particular indicators. The research results show that the efficiency of trucks has significantly decreased: the truck availability rate by $5.6 \%$, the loaded mileage proportion by $24.0 \%$, the load factor by $26.8 \%$. The decrease in the efficiency of using trucks indicates the need to develop and substantiate optimal management decisions in order to improve the use of trucks. In order to increase the validity of management decisions, it is proposed to use a new coefficient characterizing the level of use of the operating factor of technically ready trucks. This makes it possible to improve the accuracy of calculating reserves and planning the work of freight transport.
\end{abstract}

\section{Introduction}

To assess the efficiency of freight transport, a whole system of both generalizing and particular indicators is used.

This is due to the fact that some indicators make it possible to characterize a specific aspect of the operation of trucks, but do not allow comprehensive characterizing the economic efficiency of using the company's truck fleet.

Particular indicators, as a rule, allow assessing some aspects of the use of freight transport: automobile-days in operation, time spent on duty, time in motion, total mileage,

\footnotetext{
${ }^{*}$ Corresponding author: fedoskin.vladimir@yandex.ru
} 
mileage of trucks with cargo, the truck availability rate, the load factor, the loaded mileage proportion, etc.

Particular technical and operational indicators are an integral part of summarizing indicators characterizing the performance of trucks and the cost of freight, that is, with their use, the final results of work are determined and an assessment of the efficiency of using trucks is given.

According to the results of the analysis, there is usually a need to develop and substantiate the directions for increasing the efficiency of using freight transport.

\section{Materials and methods}

For the purpose of an objective analysis of the use of freight transport, a system of initial indicators has been formed that characterizes the actual average listed availability of vehicles, days of their stay at the enterprise, the number of days waiting repair, the actual number of days in operation, the total capacity, the time spent on duty, the time spent in motion, the cargo performance, annual volume of work performed (cargo turnover) [1-4].

Based on the system of indicators of the initial data, the main coefficients and indicators are calculated that characterize the efficiency of the use of freight transport (Table 1).

Table 1. Dynamics of the efficiency of using freight transport

\begin{tabular}{|c|c|c|c|c|c|c|}
\hline & 2014 & 2015 & 2016 & 2017 & 2018 & $\begin{array}{c}2018 \\
\text { to } \\
2014, \\
\%\end{array}$ \\
\hline Average number of trucks, units & 11 & 11 & 14 & 15 & 16 & 145.5 \\
\hline $\begin{array}{l}\text { Average technical capacity of the } \\
\text { truck, } t\end{array}$ & 4.70910 & 4.70910 & 3.83992 & 4.90000 & 5.34375 & 113.5 \\
\hline $\begin{array}{c}\text { Automobile-days of stay at the } \\
\text { enterprise }\end{array}$ & 4,015 & 4,015 & 5,124 & 5,475 & 5,840 & 145.5 \\
\hline $\begin{array}{l}\text { Automobile-days of the truck } \\
\text { availability: } \\
\text { a) total } \\
\text { b) per } 1 \text { truck }\end{array}$ & $\begin{array}{c}2,937 \\
267\end{array}$ & $\begin{array}{c}2,904 \\
264\end{array}$ & $\begin{array}{c}3,458 \\
247\end{array}$ & $\begin{array}{c}3,660 \\
244\end{array}$ & $\begin{array}{c}4,032 \\
252\end{array}$ & $\begin{array}{c}137.3 \\
94.4\end{array}$ \\
\hline Automobile-days in operation & 2,770 & 2,771 & 3,023 & 3,240 & 3,520 & 127.1 \\
\hline $\begin{array}{c}\text { Time spent on duty, thousand } \\
\text { hours }\end{array}$ & 20.2 & 20.4 & 24.7 & 26.0 & 26.5 & 131.2 \\
\hline Time in motion, thousand hours & 14.4 & 14.1 & 17.7 & 17.8 & 19.6 & 136.1 \\
\hline $\begin{array}{l}\text { Total mileage of trucks, thousand } \\
\text { km: } \\
\text { a) total } \\
\text { b) per } 1 \text { truck }\end{array}$ & $\begin{array}{c}536 \\
48.727\end{array}$ & $\begin{array}{c}774 \\
70.364\end{array}$ & $\begin{array}{c}1,077 \\
76.929\end{array}$ & $\begin{array}{c}1,083 \\
72.200\end{array}$ & $\begin{array}{c}1,045 \\
65.313\end{array}$ & $\begin{array}{l}195.0 \\
134.0\end{array}$ \\
\hline $\begin{array}{l}\text { Mileage of trucks with cargo, } \\
\text { thousand km: } \\
\text { a) total } \\
\text { b) per } 1 \text { truck }\end{array}$ & $\begin{array}{c}386 \\
35.091\end{array}$ & $\begin{array}{c}412 \\
37.455\end{array}$ & $\begin{array}{c}562 \\
40.143\end{array}$ & $\begin{array}{c}545 \\
36.333\end{array}$ & $\begin{array}{c}572 \\
35.750\end{array}$ & $\begin{array}{l}148.2 \\
101.9\end{array}$ \\
\hline $\begin{array}{l}\text { Completed works (freight } \\
\text { turnover), thousand tonne- } \\
\text { kilometre }\end{array}$ & 432.8 & 412.1 & 399.7 & 423.7 & 532.8 & 123.1 \\
\hline $\begin{array}{l}\text { Completed works per } 1 \text { truck, } \\
\text { tonne-kilometre }\end{array}$ & $39,345.5$ & $37,463.6$ & $28,550.0$ & $28,246.7$ & $33,300.1$ & 84.6 \\
\hline Average actual load of 1 truck, $t$ & 1.12124 & 1.000 & 0.711 & 0.77700 & 0.93147 & 83.1 \\
\hline Truck availability rate & 0.73151 & 0.72329 & 0.67486 & 0.66849 & 0.69041 & 94.4 \\
\hline The rate of trucks in operation & 0.68991 & 0.69016 & 0.58997 & 0.59178 & 0.60274 & 87.4 \\
\hline Operation factor & 0.71287 & 0.69118 & 0.71660 & 0.68462 & 0.73962 & 103.8 \\
\hline Mileage factor & 0.72015 & 0.53230 & 0.52182 & 0.50323 & 0.54737 & 76.0 \\
\hline Load factor & 0.23810 & 0.21231 & 0.18516 & 0.15857 & 0.17434 & 73.2 \\
\hline
\end{tabular}


The results of the studies, in the course of which the main indicators were calculated, characterizing the use of trucks over the past five years, made it possible to establish that the efficiency of the work of trucks has significantly decreased (Table 2).

It should be noted that for 2014-2018 the availability of trucks increased by $45.5 \%$ (or by 5 vehicles in absolute terms).

The average technical capacity of 1 truck increased by $13.5 \%$.

During the same period, the value of almost all indicators characterizing the use of freight vehicles increased.

So, the total mileage of one truck increased by $34.0 \%$ and the mileage of a loaded truck increased by $1.9 \%$.

At the same time, the volume of cargo turnover with an overall increase in the volume of work performed by $23.1 \%$ per truck decreased by $15.4 \%$ (from $39,345.5$ tonne-kilometre in 2014 to $33,300.1$ tonne-kilometre in 2018).

The value of all the coefficients characterizing the efficiency of the use of trucks has decreased quite significantly.

So, for example, the truck availability rate decreased by $5.6 \%$, the loaded mileage proportion decreased by $24.0 \%$ and the load factor decreased by $26.8 \%$.

The decrease in the efficiency of the use of trucks clearly indicates the need to develop and substantiate optimal management decisions that would significantly improve the use of trucks.

Thus, the problem arises to determine the "bottlenecks" in the management of the use of freight transport.

It seems quite realistic to solve this problem on the basis of studying the factor model of the cargo turnover of both one truck and the entire fleet.

\section{Results and discussion}

The methodological foundations of the factor analysis are quite widely covered in scientific research of Russian and foreign authors, such as Sheremet, A.D., Bakanov, M.I., Gilyarovskaya, L.T., Lysenko, D.V., Bank, V.R., Kovalev, V.V., Savitskaya, G.V., Hedderwick, K., Helfert, E. et al. [5-7].

Scientific studies of domestic and foreign economists, devoted to the theory and methodology of the factor analysis, present the basic rules and principles of the formation of factor models of various types (additive, multiplicative, multiple, etc.) and methods for assessing the impact of changing the values of factor indicators on the level of the effective indicator are developed.

The volume of work performed by trucks (cargo turnover) can be presented as a combination of factorial features.

The published scientific works highlighting the methods to assess the use of trucks present factor models of the volume of work performed, which most often consist of absolute factor indicators of the first order:

$\mathrm{VCT}=\mathrm{NT} \cdot \mathrm{ADO}^{1 \mathrm{~T}} \cdot \mathrm{DMC}^{1 \mathrm{~A}} * \mathrm{ATL}$,

where VCT is the volume of cargo turnover (volume of work performed), tonnekilometre;

NT is the average number of trucks, units;

$\mathrm{ADO}^{1 \mathrm{~T}}$ are automobile-days in operation per 1 truck;

$\mathrm{DMC}^{1 \mathrm{~A}}$ is the average daily mileage of 1 truck with cargo, $\mathrm{km}$;

ATL is the average truck load, $t$.

However, here the question naturally arises: what factors do the indicators of this multiplicative factor model depend on?

Therefore, it becomes necessary to express these factor indicators in the form of factor 
models consisting of factor indicators of the first and second orders.

It should be noted that it is necessary to apply another coefficient to characterize the operating factor of technically ready trucks, which is calculated by the ratio of the number of days in operation to the number of days in technical readiness: $\mathrm{F}^{\text {OTRT }}=\mathrm{ADO}:$ ADTA or $\mathrm{F}^{\mathrm{OTRT}}=\mathrm{ADO}^{1 \mathrm{~T}}: \mathrm{ADTA}^{1 \mathrm{~T}}$.

Then: $\left.\mathrm{ADO}^{1 \mathrm{~T}}=\mathrm{ADTA}^{1 \mathrm{~T}} \cdot \mathrm{F}^{\mathrm{OTRT}}=\left[\left(\mathrm{ADSE}^{1 \mathrm{~T}} \cdot \mathrm{R}^{\mathrm{TA}}\right) \cdot \mathrm{F}^{\mathrm{OTRT}}\right)\right]$,

where $\mathrm{ADSE}^{1 \mathrm{~T}}$ are automobile-days of stay at the enterprise per 1 truck,

$\mathrm{R}^{\mathrm{TA}}$ is the truck availability rate,

ADTA are automobile-days of trucks availability,

ADTA $^{1 \mathrm{~T}}$ are automobile-days of the truck availability per 1 truck,

$\mathrm{F}^{\mathrm{OTRT}}$ is the operating factor of technically ready trucks.

$\mathrm{DMC}^{1 \mathrm{~T}}=\left(\mathrm{ADM}^{1 \mathrm{~T}} \cdot \mathrm{P}^{\mathrm{LM}}\right)=\left[\left(\mathrm{DDM}^{1 \mathrm{~T}} \cdot \mathrm{AS}\right) \cdot \mathrm{P}^{\mathrm{LM}}\right]=\left\{\left[\left(\mathrm{TWD}^{1 \mathrm{~T}} \cdot \mathrm{R}^{\mathrm{WH}}\right) \cdot \mathrm{AS}\right] \cdot \mathrm{P}^{\mathrm{LM}}\right\}$,

where $\mathrm{ADM}^{1 \mathrm{~T}}$ is the average daily mileage of 1 truck, km;

$\mathrm{P}^{\mathrm{LM}}$ is the loaded mileage proportion;

$\mathrm{DDM}^{1 \mathrm{~T}}$ is the daily duration of 1 truck movement, hour;

$\mathrm{TWD}^{1 \mathrm{~T}}$ is the time spent on duty (daytime working hours) per 1 truck, hour;

$\mathrm{R}^{\mathrm{WH}}$ is the daytime working hours rate;

AS is the average speed, $\mathrm{km} /$ hour.

$\mathrm{ATL}=\left(\mathrm{ATC} \cdot \mathrm{F}^{\mathrm{L}}\right)$,

where ATC is the average technical capacity of 1 truck, t;

$\mathrm{F}^{\mathrm{L}}$ is the load factor.

Then the factor model of the volume of cargo turnover of 1 truck $\left(\mathrm{VCT}^{1 \mathrm{~T}}\right)$ will have the following form:

$\mathrm{VCT}^{1 \mathrm{~T}}=\left[\left(\mathrm{ADSE}^{1 \mathrm{~T}} \cdot \mathrm{R}^{\mathrm{TA}}\right) \cdot \mathrm{F}^{\mathrm{OTRT}}\right] \cdot\left\{\left[\left(\mathrm{TWD}^{1 \mathrm{~T}} \cdot \mathrm{R}^{\mathrm{WH}}\right) \cdot \mathrm{AS}\right] \cdot \mathrm{P}^{\mathrm{LM}}\right\} \cdot\left(\mathrm{ATC} \cdot \mathrm{F}^{\mathrm{L}}\right)$.

And the volume of work performed as a whole for the freight transport fleet will be expressed by the following multiplicative factor model:

$\left.\mathrm{VCT}=\mathrm{NT} \cdot\left\{\left[\left(\mathrm{ADSE}^{1 \mathrm{~T}} \cdot \mathrm{R}^{\mathrm{TA}}\right) \cdot \mathrm{F}^{\mathrm{OTRT}}\right)\right] \cdot\left\{\left[\left(\mathrm{TWD}^{1 \mathrm{~T}} \cdot \mathrm{R}^{\mathrm{WH}}\right) \cdot \mathrm{AS}\right] \cdot \mathrm{P}^{\mathrm{LM}}\right\} \cdot\left(\mathrm{ATC} \cdot \mathrm{F}^{\mathrm{L}}\right)\right\}$.

An extended factor model, including both absolute factor indicators and relative ones (coefficients), directly characterizing the efficiency of the use of freight transport, will allow a more in-depth analysis of the dynamics of the efficiency of its work and, thus, identify "bottlenecks" in the use of freight transport [8-10].

For this purpose, it is necessary to conduct a factor analysis and assess the degree of influence of changes in each factor indicator on the effective one.

Table 2. Influence of factors on the amount of work performed by one truck

\begin{tabular}{|c|c|c|c|}
\hline & 2014 & 2018 & $\begin{array}{l}\text { Deviation }(+/-) \\
2018 \text { from } 2014 \\
\end{array}$ \\
\hline $\begin{array}{l}\text { Automobile-days of stay at the enterprise per } 1 \text { truck } \\
\left(\mathrm{ADSE}^{1 \mathrm{~T}}\right)\end{array}$ & 365 & 365 & - \\
\hline Truck availability rate $\left(\mathrm{R}^{\mathrm{TA}}\right)$ & 0.73151 & 0.69041 & -0.04110 \\
\hline $\begin{array}{l}\text { Automobile-days of the truck availability per } 1 \text { truck } \\
\left(\text { ADTA }^{1 \mathrm{~T}}\right)\end{array}$ & 267 & 252 & -15 \\
\hline Operating factor of technically ready trucks $\left(\mathrm{F}^{\mathrm{OTRT}}\right)$ & 0.94314 & 0.87302 & -0.07012 \\
\hline Automobile-days in operation per 1 truck $\left(\mathrm{ADO}^{1 \mathrm{~T}}\right)$ & 251.81818 & 220.00000 & -31.81818 \\
\hline Operating factor of trucks at work $\left(\mathrm{F}^{\mathrm{OTW}}\right)$ & 0.68991 & 0.60274 & -0.07012 \\
\hline $\begin{array}{l}\text { Time spent on duty (daytime working hours) per } 1 \\
\text { truck }\left(\mathrm{TWD}^{1 \mathrm{~T}}\right) \text {, hour }\end{array}$ & 7.29242 & 7.52841 & +0.23599 \\
\hline Daytime working hours rate $\left(\mathrm{R}^{\mathrm{WH}}\right)$ & 0.71287 & 0.73962 & +0.02675 \\
\hline Daily duration of 1 truck movement $\left(\mathrm{DDM}^{1 \mathrm{~T}}\right)$, hour & 5.19856 & 5.56816 & +0.36960 \\
\hline Average speed (AS), $\mathrm{km} /$ hour & 37.22222 & 53.31633 & +16.09411 \\
\hline Average daily mileage of 1 truck $\left(\mathrm{ADM}^{1 \mathrm{~T}}\right), \mathrm{km}$ & 193.50157 & 296.87386 & +103.37229 \\
\hline Loaded mileage proportion $\left(\mathrm{P}^{\mathrm{LM}}\right)$ & 0.72015 & 0.54737 & -0.17278 \\
\hline $\begin{array}{l}\text { Average daily mileage of } 1 \text { truck with cargo } \\
\left(\mathrm{ADMC}^{\mathrm{TT}}\right), \mathrm{km}\end{array}$ & 139.35016 & 162.49984 & +23.14968 \\
\hline
\end{tabular}




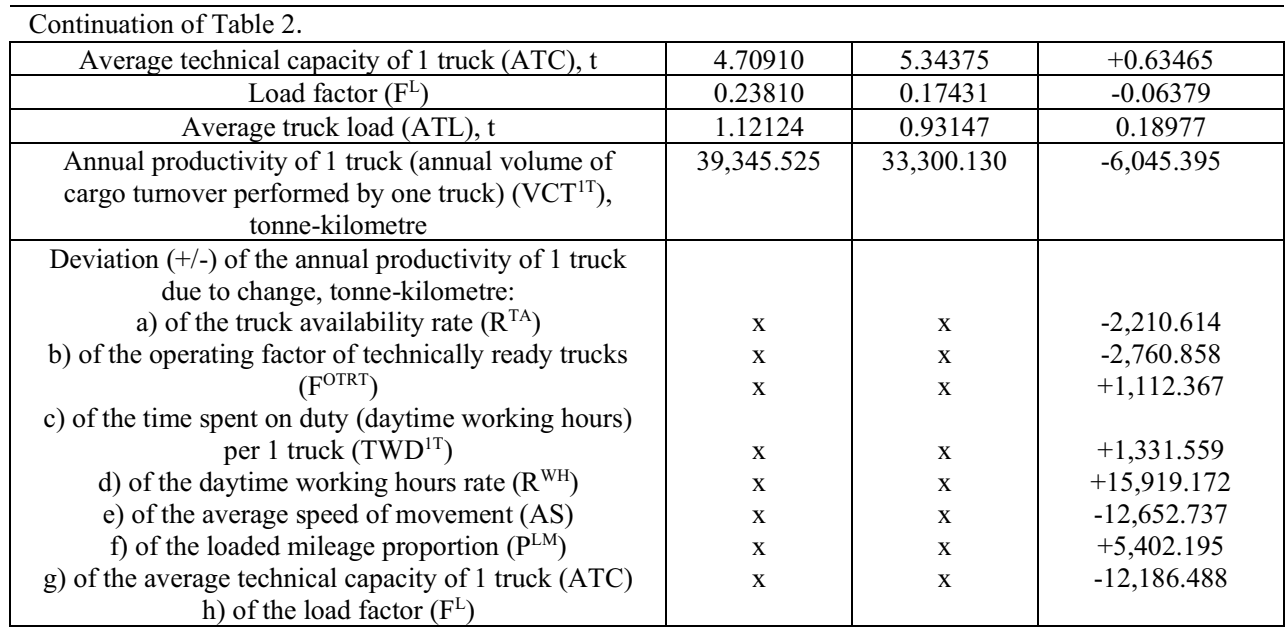

The volume of cargo turnover (per 1 truck) in 2018 compared to 2014 decreased by 6,045.395 tonne-kilometre:

$\Delta \mathrm{VCT}^{1 \mathrm{~T}}$ TOTAL $=33,300.130$ tonne-kilometre $-39,345.525$ tonne-kilometre $=$ $6,045.395$ tonne-kilometre.

The assessment of the influence of each factor is presented in Figure 1.

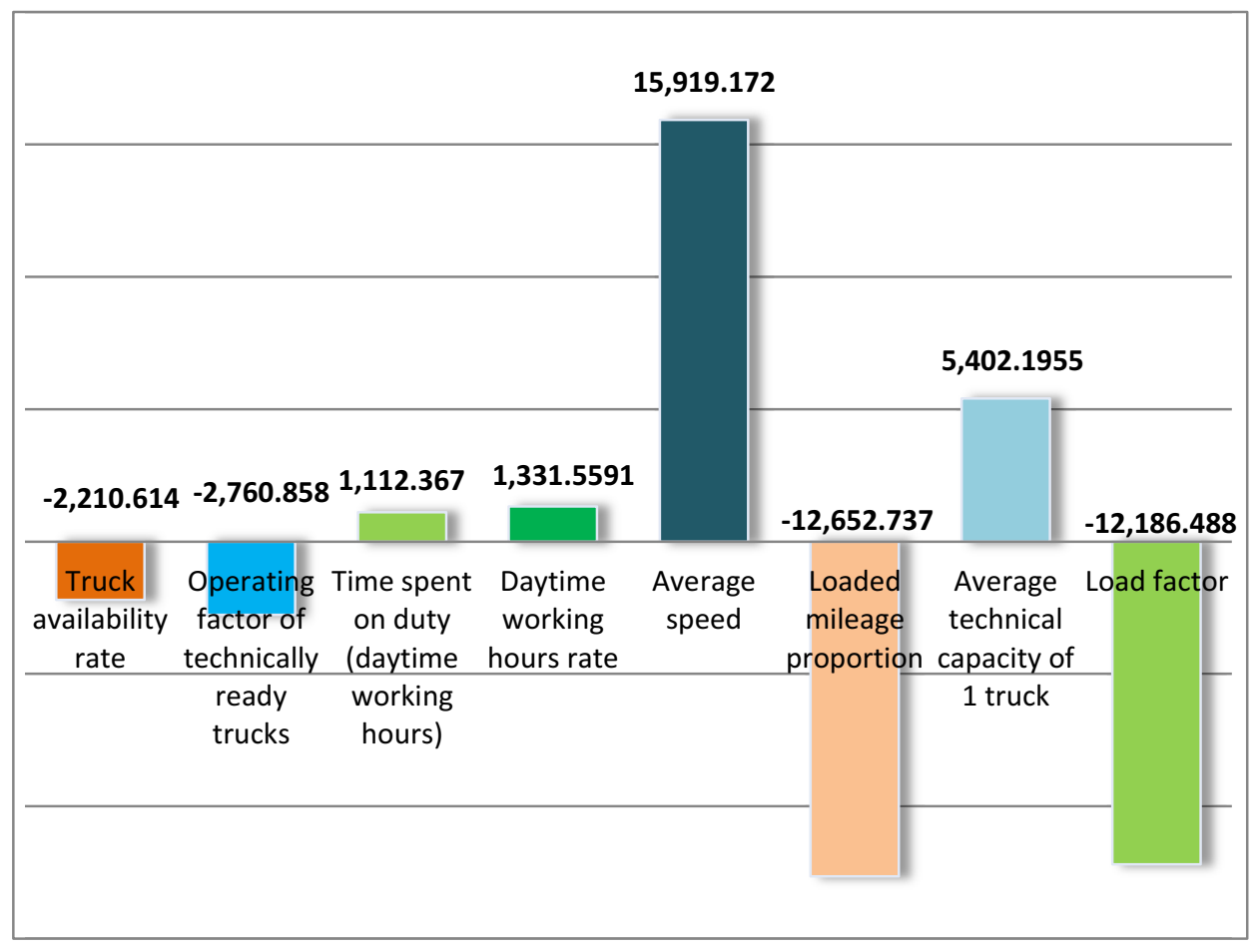

Fig. 1. Results of the factor analysis of the annual productivity of a truck.

The results of the analysis have shown that the main factors that negatively affect the volume of cargo turnover are the indicators of the efficiency of the use of freight transport. 
The results obtained, in turn, will make it possible to develop and substantiate objective and real management decisions to improve the operation of trucks and increase the efficiency of using them.

This conclusion, in our opinion, is confirmed by the following example.

The value of any coefficient can be expressed in unit fractions (which was used when calculating the coefficients given in Tables 1 and 2) and in percent.

For example, the value of the load factor in 2018 was 0.17431 in unit fractions. This will amount to $17.431 \%$, that is, the technical capacity of one truck was actually used only by $17.431 \%$ in 2018 .

The value of each coefficient will be increased by 1 percentage point as an example for mastering the planning method for the use of trucks in the future. So, the technical readiness coefficient in 2018 was 0.69041 (or 69.041\%). With an increase of 1 percentage point, its value will be $70.041 \%$ (or 0.70041 in unit fractions) [11-12].

An increase in the value of the coefficients (factor indicators) by 1 percentage point will allow to obtain an increase in the volume of work performed by one truck in the context of each factor (reserve) in the following volumes (Table 3).

Table 3. Reserves for increasing the volume of work performed by one truck

\begin{tabular}{|c|c|c|c|c|c|c|}
\hline & \multicolumn{5}{|c|}{1 percentage point increase in the value of the coefficient } & \multirow[t]{3}{*}{ TOTAL } \\
\hline & \multirow[t]{2}{*}{ availability } & \multicolumn{4}{|c|}{ the use of } & \\
\hline & & $\begin{array}{l}\text { an operating } \\
\text { factor of } \\
\text { technically } \\
\text { ready trucks }\end{array}$ & $\begin{array}{l}\text { working } \\
\text { hours }\end{array}$ & mileage & $\begin{array}{l}\text { technical } \\
\text { capacity }\end{array}$ & \\
\hline $\begin{array}{l}\text { The volume of } \\
\text { cargo turnover } \\
\text { of } 1 \text { truck, } \\
\text { tonne- } \\
\text { kilometre: } \\
\text { a) real } \\
\text { b) forecast }\end{array}$ & $\begin{array}{l}33,300.130 \\
33,782.455\end{array}$ & $\begin{array}{l}33,300.130 \\
33,681.567\end{array}$ & $\begin{array}{l}33,300.130 \\
33,750.400\end{array}$ & $\begin{array}{l}33,300.130 \\
33,908.497\end{array}$ & $\begin{array}{l}33,300.130 \\
35,210.615\end{array}$ & $\begin{array}{l}33,300.130 \\
37,133.014\end{array}$ \\
\hline $\begin{array}{l}\text { Increase in } \\
\text { freight } \\
\text { turnover: } \\
\text { a) in tonne- } \\
\text { kilometre } \\
\text { b) in } \%\end{array}$ & $\begin{array}{c}482.325 \\
1.45\end{array}$ & $\begin{array}{c}381.437 \\
1.14\end{array}$ & $\begin{array}{c}450.270 \\
1.35\end{array}$ & $\begin{array}{c}608.367 \\
1.83\end{array}$ & $\begin{array}{c}1,910.485 \\
5.74\end{array}$ & $\begin{array}{c}3,832.884 \\
11.51\end{array}$ \\
\hline
\end{tabular}

Thus, the largest planned cargo turnover will be with an increase in technical capacity by 1 percentage point.

\section{Conclusion}

In order to assess more objectively the impact of changing the values of factor indicators on the effective one (the volume of cargo turnover), an extended factor model is proposed with the inclusion of the operating factor of technically ready trucks $\left(\mathrm{F}^{\mathrm{OTRT}}\right)$, which allows more accurate assessing the level of using not all trucks in operation, but only those which were in a technically ready state.

The results of the factor analysis of the cargo turnover of one truck using the proposed factor model made it possible to identify specific factors that have a negative impact on the volume of work performed.

Based on the results obtained, an attempt was made to substantiate the reserves for increasing the volume of work performed by one truck.

For this purpose, the value of each coefficient was increased in turn by 1 percentage point and the estimated volume of cargo turnover was calculated. 
The obtained calculation results indicate that the increase in cargo turnover was obtained in quite tangible volumes (Table 3).

In addition, the amount of work that one truck can perform while increasing all coefficients by 1 percentage point has been calculated:

$\mathrm{VCT}^{1 \mathrm{~T}}{ }_{\mathrm{f}}$ (comp.) $\left.=\left[\left(\mathrm{ADSE}^{1 \mathrm{~T}}{ }_{18} \cdot \mathrm{R}_{\mathrm{f}}^{\mathrm{TA}}\right) \cdot \mathrm{F}_{\mathrm{OTRT}}\right)\right] \cdot\left\{\left[\left(\mathrm{TWD}_{18}^{1 \mathrm{~T}}{ }_{18} \cdot \mathrm{R}_{\mathrm{fH}} \mathrm{WH}_{\mathrm{f}} \cdot \mathrm{AS}_{18}\right] \cdot \mathrm{P}_{\mathrm{f}}^{\left.\mathrm{LM}_{\mathrm{f}}\right\}} \cdot\right.\right.$ $\left(\mathrm{ATC}_{18} \cdot \mathrm{F}_{\mathrm{f}}^{\mathrm{L}}\right)=37,287.289$ tonne-kilometre.

The received volume of cargo turnover is higher than the real one in 2018 by 3,987.159 tonne-kilometre (or $11.97 \%$ ), which indicates a fairly significant increase in the volume of work performed and an increase in the efficiency of using freight transport.

All calculations were performed with the necessary and optimal accuracy of the values of the factor indicators used, that has confirmed the objectivity of the results obtained.

This technique will allow to plan objectively the scope of work of freight transport with different values of factor indicators (coefficients) and choose the most optimal option.

\section{References}

1. N.V. Byshov, S.N. Borychev, G.N. Bakulina, V.V. Fedoskin, I.V. Fedoskina, M.Yu. Pikushina, Religación. revista de ciencias sociales y humanidades, 4(18), 254 (2019).

2. G. Bakulina, V. Fedoskin, M. Pikushina, V. Kukhar, E. Kot, International Journal of Circuits, Systems and Signal Processing, 14, 232 (2020).

3. E.P. Polikarpova, I.E. Mizikovskiy, Custos e Agronegocio, 14(4), 149 (2018).

4. K. Hedderwick, Financial and economic analysis of enterprises (Finance and statistics Moscow, 1996).

5. E. Helfert, Technique of financial analysis: The path to creating business value (Peter Book. Saint-Petersburg, 2003).

6. A.D. Sheremet, E.V. Negashev, Methods of financial analysis of activities at commercial organizations (INFRA-M, Moscow, 2016).

7. N.V. Byshov, I.A. Uspenskiy, I.A. Yukhin, N.V. Limarenko, IOP Conference Series: Earth and Environmental Science, 422(1), 012069 (2020).

8. N. Byshov, I. Bogdanchikov, A. Bachurin, D. Oleinik, A. Martyshov, A. Kacharmin, IOP Conf. Series: Earth and Environmental Sci. 403, 1 (2019).

9. S.D. Polischuk, G.I. Churilov, S.N. Borychev, N.V. Byshov, A.A. Nazarova, Int. J. of Nanotechnology, 15(4-5), 352 (2018).

10. R.N. Ushakov, A.V. Ruchkina, V.I. Levin, O.A. Zakharova, N.A.Golovina, Int. J. of Engin. and Tech., 7(4.36) 929 (2018).

11. M.Yu. Kostenko, A.A. Ruzimurodov, D.N. Byshov, A.A. Golakhov, N.N. Yakutin, IOP Conference Series: Earth and Environmental Science, 422(1), 012032 (2020).

12. N.V. Byshov, S.N. Borychev, I.A. Uspensky, I.A. Yukhin, A.A. Golikov, O.V. Filyushin, IOP Conference Series: Earth and Environmental Sci. 341(1), 012145 (2019). 